\title{
106. On Some New Ascigerous Stages of the Species of Helminthosporium Parasitic on Cereals.
}

\author{
By Seiya Iтo. \\ Phytopathological Laboratory, Faculty of Agriculture, \\ Hokkaido Imperial University, Sapporo. \\ (Comm. by K. MiYABE, M.I.A., Oct. 13, 1930.)
}

The ascigerous stages have been secured for a comparatively small number of the species of Helminthosporium up to the present time. In the course of the study on the Helminthosporioses of our cereals, the writer with $\mathrm{K}$. KURIBAYASHI obtained the new ascigerous stages for six species, together with two species already established by C. DRECHSLER, Pyrenophora teres (SACC.) DRECHSLER ${ }^{1)}$ and Ophiobolus heterostrophus Drechsler." Among these six new species, Ophiobolus Miyabeanus S. Ito et KURIB. ${ }^{3)}$ and Oph. sativus (P. K. et B.) S. Ito et KurIB." have already been reported by us in 1927 and 1929 respectively. In the present paper it is intended to report on the remaining four unrecorded ascigerous forms.

\section{Ophiobolus Setariae (SAw.) S. ITo et KURIB. sp. nov.}

Conidial stage $=$ Helminthosporium Setariae SAWADA.

Ascigerous stage-Perithecia dark brownish, pseudoparenchymatous, flask-shaped, with ostiolar beak; bodies globose or short ellipsoidal, 240-500 $\times 220-315 \mu$; beaks well developed, paraboloid or cylindrical, 60-125 $\times 50-110 \mu$. Asci numerous, fusiform, straight or slightly curved, widest somewhat below the middle, rounded at the apex, shortly stipitate at the base, hyaline, thin-walled, $130-150 \times 22-32 \mu$, with 1 to 8 ascospores. Ascospores filiform, obtusely pointed at both ends, 5-9septate, coiled in a close helix, 200-315 $\times 6-7 \mu$, hyaline or light olive colored in low magnification.

1) C. Drechsler: Some graminicolous species of Helminthosporium: I (Jour. Agr. Res., 24, 641-739, 1923).

2) C. DREChSLER: Leafspot of maize caused by Ophiobolus heterostrophus, n. sp., the ascigerous stage of a Helminthosporium exhibiting bipolar germination (Jour. Agr. Res., 31, 701-726, 1925).

3) S. ITo and K. Kuribayashi: Production of the ascigerous stage in culture of Helminthosporium Oryzae (Ann. Phytopath. Soc. Japan, 2, No. 1, 1-8, 1927).

4) K. KURIBAYASHI: The ascigerous stage of Helminthosporium sativum (Trans. Sapporo Nat. Hist. Soc., 10, 138-145, 1929). 
No. 8.] On Some New Ascigerous Stages of the Species of Helminthosporium.

Hab. On Setaria italica BEAUv. var. germanica TRIN., S. glauca Beauv., S. viridis Beauv. and its var. purpurascens MaXIM.

Pyrenophora graminea (RABH.) S. ITo et KURIB. sp. nov. Conidial stage $=$ Helminthosporium gramineum RABH.

Ascigerous stage-Perithecia developing on fully rotten straw or stubble of the host-plant affected in the growing season, at first covered by the epidermis, then erumpent, scattered, globose when young, later flask-shaped or conical by the formation of ostiolar beak; wall blackishbrown, thick, pseudoparenchymatous, more or less firm, provided with many long setae and condiophores on the surface; bodies $350-850 \mu$ in height, $450-800 \mu$ in long diam., $350-700 \mu$ in short diam., ostiolar beaks short paraboloid or cylindrical. Asci numerous, fasciculate, long clavate, wall thick when young, thin at maturity, hyaline, firm, $225-425 \times 32-50 \mu$, with 1 to 8 , mostly 4 or 8 ascospores. Ascospores yellowish-brown, ellipsoidal, rounded at both ends, with 3 , rarely 2 transverse septa, without or with 1 or 2 longitudinal septa in the median cells, remarkably constricted at the septum, wall hayline, with gelatinous sheath, $45-75 \times 20-32.5 \mu$.

Hab. On Hordeum sativum JESS. (common and nacked barley).

Pyrenophora japonica S. ITo et KURIB. sp. nov.

Conidial stage-Conidia sooty brown, cylindrical, straight, rounded at both ends, 2-9-, mostly 4-6-septate, scarcely constricted at the septum, thin-walled, $42-145 \times 15-18 \mu$. Germinating by a germ-tube from each cell.

Ascigerous stage-Perithecia developing on half rotten straw or stubble of the host-plant affected or not in the growing season, at first covered by the epidermis, then erumpent, easily ripened, flask-shaped or conical; wall blackish-brown, pseudoparenchymatous, rather firm, provided with many setae and conidiophores on the surface; bodies 300-600 $\mu$ in height, $400-700 \mu$ in long diam., $350-500 \mu$ in short diam., ostiolar beaks short paraboloid or cylindrical. Asci numerous, fasciculate, clavate, more or less curved, rounded at the apex, shortly stipitate at the base, thick-walled when young, thin at maturity, hyaline, firm, 225-350 (rarely up to $400 \mu$ ) $\times 35-45 \mu$, with 8 ascospores. Ascospores yellowish-brown, ellipsoidal, rounded at both ends, with 3 transverse septa, without or with 1 or 2 longitudinal septa in the 
median cells, remarkably constricted at the septum, hyaline, thin-walled, $40-65 \times 17.5-30 \mu$.

Hab. On Hordeum sativum JEsS. (common and naked barley).

Pyrenophora Avenae (EIDAM) S. ITo et KURIB. sp. nov.

Conidial stage $=$ Helminthosporium Avenae EIDAM.

Ascigerous stage-Perithecia developing on half rotten straw, grains or stubble of the host-plant affected or not in the growing season, at first covered by the epidermis, then erumpent, semiglobose when young, then flask-shaped or conical; wall blackish-brown, pseudoparenchymatous, provided with many long setae and conidiophores on the surface; bodies 300-600 $\mu$ in height, $450-800 \mu$ in long diam., $350-700 \mu$ in short diam. ; ostiolar beaks short paraboloid or cylindrical. Asci numerous, fasciculate, clavate or cylindrical, often slightly curved, rounded at the apex, shortly stipitate at the base, hyaline, firm-walled, $250-350 \mu$, rarely up to $400 \mu$ in length, $35-45 \mu$ in width, with 2 to 8 , mostly 8 ascospores. Ascospores light yellowish or yellowish-brown, ellipsoidal or oval in shape, rounded at both ends, with 3-6, mostly 5 transverse septa, without or with 1 to 4 longitudinal septa, remarkably constricted at the septum, wall hyaline, thin, with outer gelatinous sheath, $50-75 \times 17.5-30 \mu$.

Hab. On Avena sativa L. and Av. fatua L.

The ascigerous forms of the four species of Ophiobolus above mentioned were secured only in cultures and not collected in a field. These species are distinguishable by the morphological characters of the conidia, while their perithecia are rather similar to one another. The analytical key to these species is given as follows:-

I. Ostiolar beaks of perithecia without any seta

1. Ascospores mostly flagelliform, often septate more than ten; conidial wall firm................................. Ophiobolus Miyabeanus

2. Ascospores mostly filiform, septate less than ten

A. Conidial wall firm ................... Oph. heterostrophus

B. Conidial wall fragile .................. Oph. Setariae

II. Ostiolar beaks of perithecia with setae (or immature conidiophores); ascospores often septate more than ten; conidial wall fragile Oph. sativus 
No. 8.] On Some New Ascigerous Stages of the Species of Helminthosporium.

The ascigerous forms of the four species of Pyrenophora above mentioned were collected on straw or stubble of their respective hostplants. The conidia are so similar that we could hardly distinguish them from one another, and they are distinguishable by the morphological characters of the ascospores as well as by the cultural and biological characters. The analytical key to them is given as follows:-

I. Ascospores typically with three transverse septa

1. Claw-like hyphal band not produced in culture

A. Conidial formation greatly suppressed in culture .........................Pyrenophora graminea

B. Conidial formation vigorous in culture ...Pyr. japonica

2. Claw-like hyphal band produced in culture......Pyr. teres

II. Ascospores typically with five transverse septa; claw-like hyphal band not produced; conidial formation vigorous in culture ....................Pyr. Avenae

Y. Nishikado in 1928 after a historical review of the genus Helminthosporium proposed to divided it into two subgenera, Eu- or Fuso-Helminthosporium and Cylindro-Helminthosporium. The first subgenus includes 17 species, which have fusiform, long ellipsoidal, obclavate or obovate, usually curved conidia, germinating by two polar germtubes and associated with Ophiobolus. The second subgenus includes 7 species, which have cylindrical, not curved conidia, germinating from every cell and associated with Pyrenophora. The proposition was affirmed by the increase of the number of the ascigerous forms in our experiments as above stated. It seems to be more natural and reasonable that the second subgenus should be separated from Helminthosporium proper and elevated to a distinct generic rank. As Cylindro-Helminthosporium is too long and improper for a generic name, the writer wishes to propose a new one, Drechslera, in honour of Dr. C. DREChsLer who has largely contributed to our knowledge of the genus Helminthosporium. The following species naturally fall within the boundary of the new genus:

Helminthosporium Arundinis LÉv.=Drechslera Arundinis (LÉv.) S. Iто ; Hel. catenarium DRECHS.=Drechslera catenaria (DRECHS.) S. ITo ; Hel. giganteum HEALD et WoLF = Drechslera gigantea $(\mathrm{H}$. et W.) S. ITо; Hel. Tritici-vulgaris NISH.=Drechslera Tritici-vulgaris (NISH.) S. ITo; and the conidial stages of Pyrenophora graminea, Pyr. teres, Pyr. japonica, Pyr. Avenae, Pyr. Bromi and Pyr. Tritici-repentis. 